\title{
Wybrane aspekty pomiaru koopetycji w kontekście orientacji przedsiębiorczej organizacji ${ }^{1}$
}

Dr Rafał Kusa

AGH Akademia Górniczo-Hutnicza w Krakowie, Wydział Zarządzania Katedra Zarządzania Organizacjami, Kadrami i Prawa Gospodarczego

\section{Wprowadzenie}

Relacje między organizacjami przyjmują różnorakie formy. Obok tradycyjnych relacji konkurowania i współpracy coraz częstsza jest koopetycja, zakładająca równoczesne konkurowanie i współpracę pomiędzy tymi samymi podmiotami. Koopetycja analizowana jest w ramach nauk o zarządzaniu z wykorzystaniem współczesnych koncepcji i teorii ekonomicznych (m.in. koncepcji zasobowej, teorii kosztów transakcyjnych, teorii gier ${ }^{2}$ ). Jednakże wiedza na temat koopetycji jest wciąż niewystarczająca. Jednym z obszarów wymagających poznania są związki pomiędzy koopetycją i przedsiębiorczością ${ }^{3}$. Badania w tym obszarze wymagają opracowania odpowiedniej metodyki, włącznie z przygotowaniem narzędzi do pomiaru stopnia zależności pomiędzy oboma zjawiskami.

Celem rozdziału jest określenie potencjalnych związków pomiędzy koopetycją i przedsiębiorczością oraz wskazanie zagadnień, które powinny być uwzględnione w dalszych badaniach poświęconych tym zależnościom. Oprzcowanie ma charakter empiryczno-koncepcyjny. Została w nim przeprowadzona wstępna empiryczna weryfikacja związków pomiędzy koopetycją a wymiarami orientacji przedsiębiorczej (gotowością do podejmowania ryzyka, innowacyjnością, proaktywnością)

1 Rozdział powstał w ramach projektu badawczego pt. „Współpraca międzyorganizacyjna jako przejaw orientacji przedsiębiorczej", wspieranego przez Narodowe Centrum Nauki (numer rejestracyjny: 2018/02/X/HS4/02934).

2 W. Mierzejewska, Czynniki sukcesu koopetycji, „Zarządzanie i Finanse. Journal of Management and Finance" 2018, t. 16, nr 1, s. 124.

3 N. Roig-Tierno, S. Kraus, S. Cruz, The relation between coopetition and innovation/entrepreneurship, „Review of Managerial Science” 2018, vol. 12, no. 2, s. 379. 
na poziomie organizacji. W tym celu skonstruowano miarę intensywności koopetycji. Badania przeprowadzono na próbie małych i średnich przedsiębiorstw, zróżnicowanych pod względem przedmiotu prowadzonej działalności. Ponadto wskazane zostały szczegółowe zagadnienia i zaproponowane pytania, które mogą być wykorzystane do budowy narzędzia umożliwiającego bardziej szczegółowy pomiar i opis powiązań pomiędzy koopetycją i przedsiębiorczością. Rozdział bazuje na literaturze z zakresu przedsiębiorczości i koopetycji, ze szczególnym uwzględnieniem opracowań dotyczących związków pomiędzy tymi zjawiskami.

\section{Istota koopetycji}

Koopetycja (określana także jako kooperencja) definiowana jest jako układ ,jednoczesnych i współzależnych relacji konkurencji i kooperacji między konkurentami zachowującymi swoją odrębność organizacyjną"4 . Koopetycja może przejawiać się poprzez inicjatywy o charakterze strategicznym, a także operacyjnym (np. wspólna obsługa klientów, wymiana komplementarnych zasobów, wspólne działania promocyjne czy wzajemne doradztwo ${ }^{5}$ ). Odgrywa ona na tyle istotną rolę we współczesnej gospodarce, że traktowana jest jako odrębny rodzaj relacji międzyorganizacyjnych ${ }^{6}$.

Koopetycja jest postrzegana jako strategiczny czynnik konkurencyjności przedsiębiorstw $^{7}$ lub wręcz jako strategia, która umożliwia zrównoważony rozwój przedsiębiorstwa ${ }^{8}$. Wśród korzyści związanych z koopetycją znajdują się: zwiększenie sprzedaży i udziału w rynku ${ }^{9}$, dostęp do nowych rynków ${ }^{10}$, zwiększenie możliwości wprowadzania innowacji produktowych ${ }^{11}$, wzrost innowacyjności

4 J. Cygler, Kooperencja przedsiębiorstw. Czynniki sektorowe i korporacyjne, Oficyna Wydawnicza SGH - Szkoła Główna Handlowa w Warszawie, Warszawa 2009, s. 19.

5 K. Czernek, Formy i uwarunkowania koopetycji na obszarach turystycznych, „Przedsiębiorczość i Zarządzanie" 2018, t. XIX, z. 6, cz. II, s. 91-104.

6 M. Aluchna, Kooperencja w grupach kapitałowych, [w:] M. Aluchna i wsp., Kooperencja przedsiębiorstw w dobie globalizacji. Wyzwania strategiczne, uwarunkowania prawne, Wolters Kluwer, Warszawa 2013, s. 173.

7 N. Roig-Tierno, S. Kraus, S. Cruz, The relation...

8 J. Cygler i wsp., Benefits and Drawbacks of Coopetition: The Roles of Scope and Durability in Coopetitive Relationships, „Sustainability” 2018, vol. 10, no. 2688.

9 F. Rodrigues, V. Souza, J. Leitão, Strategic coopetition of global brands: a game theory approach to 'Nike+ iPod Sport Kit' co-branding, ,International Journal of Entrepreneurial Venturing" 2011, vol. 3, no. 4, s. 435-455.

10 M.H. Morris, A. Koçak, A. Özer, Coopetition as a small business strategy: implications for performance, „Journal of Small Business Strategy” 2007, vol. 18, no. 1, s. 35-36.

11 R. Bouncken i wsp., Coopetition in new product development alliances - advantages and tensions for incremental and radical innovation, „British Journal of Management” 2018, vol. 29, no. 3, s. 391-410. 
organizacyjnej $^{12}$, w tym stymulowanie innowacyjności w zakresie modeli bizne$\mathrm{su}^{13}$. Koopetycja umożliwia rozwój produktów, których dane przedsiębiorstwo nie byłoby w stanie rozwijać samodzielnie, lub też trwałoby to zbyt długo ${ }^{14}$. Badania wskazują, że koopetycja w wymiarze międzynarodowym wspiera wprowadzanie radykalnych innowacji ${ }^{15}$. Znaczenie koopetycji jest różne na poszczególnych etapach rozwoju przedsiębiorstw, jak również na poszczególnych etapach procesu innowacyjnego ${ }^{16}$, a ponadto jej wpływ na rozwój uzależniony jest od charakterystyki firmy (np. wielkości, innowacyjności, otwartości na rynki międzynarodowe, zasobów wiedzy, wykorzystywanych technologii) ${ }^{17}$. Korzyści związane z koopetycją wynikają między innymi z podziału kosztów i ryzyka, ekonomii skali ${ }^{18}$, wspólnie realizowanej działalności badawczo-rozwojowej ${ }^{19}$, dostępu do wiedzy i zasobów zewnętrznych ${ }^{20}$. Mówiąc o korzyściach związanych z koopetycją, należy wskazać na możliwość pojawienia się jej negatywnych następstw, takich jak ograniczenie elastyczności i niezależności przedsiębiorstwa, oportunizm, pojawiające się konflikty interesów i trudności w koordynacji działań koopetycyjnych ${ }^{21}$.

Relacje koopetycyjne mogą być zdominowane przez współpracę, zrównoważone lub zdominowane przez konkurencję ${ }^{22}$. Działania koopetycyjne mogą mieć charakter bezpośredni lub pośredni ${ }^{23}$ i mogą odnosić się do różnych rodzajów

12 P. Klimas, W. Czakon, Organizational innovativeness and coopetition: a study of video game developers, „Review of Managerial Science” 2018, vol. 12, s. 480.

13 P. Ritala, L.-M. Sainio, Coopetition for radical innovation: technology, market and business-model perspectives, „Technology Analysis \& Strategic Management” 2014, vol. 26, no. 2, s. 155.

14 K. Walley, Coopetition: an introduction to the subject and an agenda for research, „International Studies of Management \& Organization" 2007, vol. 37, no. 2, s. 11.

15 V.Vanyushyn i wsp., International coopetition for innovation: are the benefits worth the challenges?, „Review of Managerial Science” 2018, no. 12, s. 535.

16 A. Osarenkhoe, A study of inter-firm dynamics between competition and cooperation - a coopetition strategy, ,Journal of Database Marketing \& Customer Strategy Management” 2010, vol. 17, no. 3-4, s. 201.

17 A. Zakrzewska-Bielawska, Koopetycja a rozwój przedsiębiorstwa w opinii kadry kierowniczej firm high-tech, „Zeszyty Naukowe Politechniki Łódzkiej: Organizacja i Zarządzanie” 2013, nr 52, s. 135.

18 D.R. Gnyawali, B.J.R. Park, Co-opetition and technological innovation in small and medium-sized enterprises: a multilevel conceptual model, „, Journal of Small Business Management” 2009, vol. 47, no. 3, s. 308-330; W. Hora i wsp., David and Goliath: causes and effects of coopetition between start-ups and corporates, „Review of Managerial Science” 2018, no. 12, s. 411-439.

19 K. Walley, Coopetition: an introduction...

20 M. Bengtsson, S. Kock, Coopetition in business networks - to cooperate and compete simultaneously, „Industrial Marketing Management” 2000, vol. 29, no. 5, s. 411.

21 W. Mierzejewska, Czynniki sukcesu...

22 Tamże.

23 S. Kraus i wsp., In search for the ideal coopetition partner: an experimental study, „Review of Managerial Studies" 2017, no. 12, s. 1025. 
działań realizowanych przez przedsiębiorstwo (zarówno działań podstawowych, jak i drugorzędnych) ${ }^{24}$. Koopetycja może występować także w sieciach i obejmować równocześnie wiele podmiotów ${ }^{25}$.

Rozpoczęcie, a następnie sukces działań w zakresie koopetycji są uwarunkowane wieloma czynnikami. Należą do nich: rozwój relacji i zarządzanie komunikacją pomiędzy uczestnikami koopetycji, zaangażowanie osób zarządzających ${ }^{26}$, sposób myślenia ${ }^{27}$ oraz postawa reprezentowana przez właściciela czy menedżera przedsiębiorstwa $^{28}$ (determinująca ich decyzje dotyczące podjęcia współpracy z konkurentami), zaufanie pomiędzy współpracującymi konkurentami, poczucie przynależności do lokalnej wspólnoty oraz silne więzi społeczne z jej członkami (stymulujące koopetycję), bliskość lokalizacji konkurentów czy istnienie lokalnego lidera koordynującego współpracę między konkurentami ${ }^{29}$, a także charakterystyka wspólnie realizowanych przedsięwzięć ${ }^{30}$. Koopetycja może być zamierzonym i celowym działaniem, ale może także wystąpić w sposób nieplanowany, z niejasno określonymi na wstępie celami ${ }^{31}$.

Ocena intensywności koopetycji na poziomie organizacji wymaga uwzględnienia poziomu zaangażowania we współpracę z konkurentami (zarówno w skali krajowej, jak i międzynarodowej), w odniesieniu do stopnia, w jakim konkurują na swoich rynkach i w porównaniu do innych podmiotów w danej branży. Każdy aspekt koopetycji wymaga pomiaru za pomocą kilku wskaźników ${ }^{32}$. W dotychczasowych badaniach koopetycji wykorzystywane były pytania odnoszące się do kontaktów między organizacjami, oceny (swojej i parterów) realizowanej współpracy oraz rywalizacji, oczekiwań dotyczących przyszłego rozwoju relacji, procesów decyzyjnych, miejsca współpracy w strategii czy celów i oczekiwań związanych ze współpracą ${ }^{33}$. W badaniach poświęconych czynnikom wpływającym na podjęcie decyzji

24 P. Klimas, W. Czakon, Organizational innovativeness...

25 W. Czakon, Network coopetition, [w:] A.-S. Fernandez i wsp. (red.), The Routledge Companion to Coopetition Strategies, Routledge, Abingdon 2018.

26 K.S. Chin, B.L. Chan, L. Ping-Kit, Identifying and prioritizing critical success factors for coopetition strategy, „Industrial Management \& Data Systems” 2008, vol. 108, no. 4. s. 437.

27 W. Czakon, P. Klimas, M. Mariani, Behavioral antecedents of coopetition: A synthesis and measurement scale, „Long Range Planning” 2020, vol. 53, no. 1, 101875.

28 K. Czernek, Formy i uwarunkowania koopetycji...

29 Tamże.

30 E. Rychłowska-Musiat, Value Creation in a Firm Through Coopetition: Real Options Games Approach, [w:] K. Jajuga, L. Orlowski, K. Staehr (red.), Contemporary Trends and Challenges in Finance, Springer Proceedings in Business and Economics, Springer, Cham 2017.

31 T. Galkina, E.-L. Lundgren-Henriksson, Coopetition as an entrepreneurial process: Interplay of causation and effectuation, „Industrial Marketing Management” 2017, no. 67, s. 158.

32 J.M. Crick, D. Crick, Developing and validating a multi-dimensional measure of coopetition, „Journal of Business \& Industrial Marketing” 2019, vol. 34, no. 4, s. 665.

33 T. Galkina, E.-L. Lundgren-Henriksson, Coopetition as an entrepreneurial process... 
o zaangażowaniu w relacje koopetycyjne uwzględnione zostały przez badaczy takie czynniki jak: postrzegane korzyści, strategiczne dopasowanie, reputacja partnera, dotychczasowy udział w sieciach partnerskich, zaufanie do partnerów, orientacja na współpracę i dotychczasowe doświadczenia w koopetycji. Wszystkie one mogą mieć wpływ na podjęcie decyzji o zaangażowaniu w relacje koopetycyjne ${ }^{34}$.

\section{Przedsiębiorczość i orientacja przedsiębiorcza}

Przedsiębiorczość jest zjawiskiem uwidaczniającym się na różnych poziomach: osób organizacji, gospodarek. W niniejszym opracowaniu będzie ona analizowana na poziomie organizacji. W tym kontekście przedsiębiorczość przejawia się poprzez tworzenie nowych organizacji ${ }^{35}$ przez indywidualnych przedsiębiorców oraz w ramach już funkcjonujących organizacji (co jest przedmiotem analiz w ramach koncepcji przedsiębiorczości organizacyjnej36 i korporacyjnej37). Głównym motywem tworzenia organizacji i zarazem istotą przedsiębiorczego działania jest dążenie do wykorzystania sposobności ${ }^{38}$, rozumianych jako „sytuacje, w których nowe dobra, usługi, materiały i metody organizacyjne mogą zostać rozpoznane i sprzedane po cenie wyższej niż koszt produkcji"39. Ukierunkowanie na sposobności może stanowić podstawę strategii organizacji, w ramach której tworzone są warunki do ich wykorzystania, w tym zapewniana jest dostępność do zasobów ${ }^{40}$. Przedsiębiorczość organizacyjna jest zjawiskiem wielowymiarowym i jej analiza wymaga uwzględnienia różnych atrybutów, etapów procesu przedsiębiorczego, zależności przyczynowo-skutkowych czy kompetencji przedsiębiorczych ${ }^{41}$. Jednym z powszechnie przywoływanych sposobów operacjonalizacji przedsiębiorczości organizacyjnej jest koncepcja orientacji przedsiębiorczej. Bazuje on na definicji,

34 W. Czakon, P. Klimas, M. Mariani, Behavioral antecedents of coopetition...

35 W.B. Gartner, „Who Is an Entrepreneur?” Is the Wrong Question, „Entrepreneurship Theory and Practice" 1989, Summer, s. 47.

36 W. Dyduch, Pomiar przedsiębiorczości organizacyjnej, Wydawnictwo Uniwersytetu Ekonomicznego w Katowicach, Katowice 2008.

37 M.H. Morris, D.F. Kuratko, Corporate Entrepreneurship: Entrepreneurial Development within Organizations, Thomson South-Western, Mason 2002, s. 31.

38 H.H. Stevenson, J.C. Jarillo, A Paradigm of Entrepreneurship: Entrepreneurial Management, "Strategic Management Journal” 1990, vol. 11, no. 4, s. 23.

39 S. Shane, S. Venkatraman, The promise of entrepreneurship as a field of research, „Academy of Management Review" 2000, no. 25, s. 220.

40 R. Krupski, O okazjach raz jeszcze: trochę teorii i raportu z badań, „Przegląd Organizacji” 2012, nr 11, s. 3.

41 R. Kusa, Wielowymiarowa analiza przedsiębiorczości organizacyjnej, [w:] A. Zakrzewska-Bielawska (red.), Stan i perspektywy rozwoju nauk o zarzq̨dzaniu. Wybrane problemy, Towarzystwo Naukowe Organizacji i Kierownictwa „Dom Organizatora”, Toruń 2016, s. 482. 
zgodnie z którą organizacja przedsiębiorcza „angażuje się w produktowe innowacje rynkowe, podejmuje ryzykowne przedsięwzięcia i która jako pierwsza wymyśla 'proaktywne' innowacje, pokonując konkurentów"42. Na podstawie tej definicji wyodrębniono trzy podstawowe atrybuty przedsiębiorczości: innowacyjność, proaktywność i gotowość do podejmowania ryzyka, poszerzane w innych operacjonalizacjach orientacji przedsiębiorczej o dwa dodatkowe wymiary: autonomię pracowników i nastawienie konkurencyjne ${ }^{43}$.

Postawa przedsiębiorcza jest zwykle utożsamiana z gotowością do rywalizacji (niekiedy wręcz z agresywnym konkurowaniem ${ }^{44}$ ), natomiast w niewielkim stopniu łączona jest z postawą kooperacyjną. Tymczasem przedsiębiorcze organizacje mają potencjał do rozwijania relacji partnerskich ${ }^{45}$, co jest postrzegane jako przejaw innowacyjności i proaktywności ${ }^{46}$, a wręcz czyni je przedsiębiorczymi ${ }^{47}$. Umiejętność współpracy jest pożądana u każdego przedsiębiorcy ${ }^{48}$. W kontekście przedsiębiorczości na poziomie organizacji umiejętność współpracy jest utożsamiana z przedsiębiorczością kolaboracyjną (collaborative entrepreneurship) ${ }^{49}$. Nie kwestionując znaczenia konkurowania, należy uznać rolę współpracy w przedsiębiorczych działaniach. Co więcej, w pogoni za sposobnościami przedsiębiorca może współpracować także z konkurentami (co stanowi istotę koopetycji). Elastyczność w kształtowaniu relacji z innymi podmiotami (wyrażająca się także poprzez gotowość do współpracy z konkurentami) wydaje się istotniejszym przejawem przedsiębiorczości niż gotowość do rywalizacji.

42 D. Miller, The correlates of entrepreneurship in three types of firms, „Management Science” 1983, vol. 29, no. 7, s. 770.

43 G.T. Lumpkin, G.G. Dess, The Entrepreneurial Orientation Construct and Linking It to Performance, „Academy of Management Review” 1996, vol. 21, no. 1, s. 135-172.

44 Tamże.

45 D. Ribeiro-Soriano, D. Urbano, Overview of collaborative entrepreneurship: An integrated approach between business decisions and negotiations, „Group Decision Negotiation” 2009, no. 18, s. 419.

46 M. Franco, H. Haase, Firm resources and entrepreneurial orientation as determinants for collaborative entrepreneurship, „Management Decision” 2013, vol. 51, no. 3, s. 680.

47 D. Ribeiro-Soriano, D. Urbano, Overview of collaborative entrepreneurship...

48 T. Boyles, 21st century knowledge, skills, and abilities and entrepreneurial competences: A model for undergraduate entrepreneurship education, „Journal of Entrepreneurship Education” 2012, no. 15, s. 41-55.

49 D. Ribeiro-Soriano, D. Urbano, Overview of collaborative entrepreneurship... 


\section{Metodyka i rezultaty badań}

W celu określenia potencjalnych związków pomiędzy koopetycją i przedsiębiorczością na poziomie organizacji przeprowadzono badania empiryczne. Badanymi zmiennymi były: intensywność koopetycji, gotowość do podejmowania ryzyka, innowacyjność i proaktywność. Ponadto wprowadzono zmienną obrazującą wyniki osiągane przez przedsiębiorstwa, aby skonfrontować związki pomiędzy wynikami a koopetycją ze związkami z wymiarami orientacji przedsiębiorczej.

Do określenia wymiarów orientacji przedsiębiorczej wykorzystano wskaźniki bazujące na skali zaproponowanej przez Hughesa i Morgana ${ }^{50}$. Po modyfikacji wskaźnik odzwierciedlający gotowość do podejmowania ryzyka obejmował cztery elementy, innowacyjność - cztery elementy, proaktywność - pięć elementów, natomiast wyniki uzyskiwane przez przedsiębiorstwo - sześć elementów. Wszystkie oceniane były w siedmiostopniowej skali (gdzie 1 oznaczało „w pełni nie zgadzam się", a 7 „w pełni zgadzam się”). Natomiast w celu określenia intensywności koopetycji na poziomie przedsiębiorstwa zaproponowana została nowa miara, obejmująca cztery wskaźniki ${ }^{51}$ (także oceniane w skali siedmiostopniowej). Przyjęły one postać następujących stwierdzeń:

- W celu wykorzystania napotkanych okazji współpracujemy lub jesteśmy gotowi podjąć współpracę nawet z naszymi konkurentami.

- Dostarczamy lub jesteśmy gotowi dostarczać nasze produkty naszym konkurentom i/lub kupować ich produkty.

- Często współpracujemy z naszymi konkurentami (nigdy - 1; regularnie - 7).

- Współpraca z konkurentami jest dla nas źródłem znacznych korzyści.

Współczynnik alfa-Cronbacha dla tak skonstruowanej miary wynosi 0,88 , co pozwala na stwierdzenie rzetelności miary na satysfakcjonującym poziomie ${ }^{52}$. Usunięcie któregokolwiek elementu powodowałoby osłabienie współczynnika alfa-Cronbacha. Współczynniki alfa-Cronbacha dla wszystkich zmiennych przedstawione są w tabeli 1.

Badania związków pomiędzy koopetycją a atrybutami przedsiębiorczości i wynikami przedsiębiorstw przeprowadzone zostały na próbie 358 przedsiębiorstw sektora MSP (z wyłączeniem przedsiębiorstw zatrudniających mniej niż sześciu pracowników). Badane przedsiębiorstwa reprezentowały następujące rodzaje

50 M. Hughes, R.E. Morgan, Deconstructing the relationship between entrepreneurial orientation and business performance at the embryonic stage of firm growth, ,Industrial Marketing Management" 2007, no. 36, s. 651-661.

51 Zostaty one wybrane spośród szerszej grupy testowanych wskaźników na podstawie analizy ich wpływu na rzetelność proponowanego współczynnika intensywności koopetycji.

52 J.C. Nunnally, I.H. Bernstein, Psychometric Theory, McGraw-Hill Inc., New York 1967. 
działalności: produkcja komputerów, wyrobów elektronicznych i optycznych; produkcja wyrobów tekstylnych; produkcja odzieży; produkcja mebli; turystyka, edukacja i sport; edukacja. Dane gromadzone były na terenie czterech województw: mazowieckiego, wielkopolskiego, dolnośląskiego i opolskiego, w okresie od stycznia do lutego 2020 roku.

Zależności pomiędzy badanymi zmiennymi (intensywnością koopetycji, gotowością do podejmowania ryzyka, innowacyjnością, proaktywnością i wynikami przedsiębiorstw) określono poprzez wyznaczenie współczynników korelacji. Ich wartości przedstawione są $\mathrm{w}$ tabeli 1.

Tabela 1. Wartości średnie, współczynniki korelacji i rzetelności badanych zmiennych $(n=358)$

\begin{tabular}{|l|c|c|c|c|l|l|l|}
\hline \multicolumn{1}{|c|}{ Zmienna } & $\begin{array}{c}\text { Alfa } \\
\text { Cronbacha }\end{array}$ & Średnia & $\begin{array}{c}\text { Odch. } \\
\text { stand. }\end{array}$ & Ryzyko & $\begin{array}{c}\text { Innowa- } \\
\text { cyjność }\end{array}$ & $\begin{array}{c}\text { Proaktyw- } \\
\text { ność }\end{array}$ & Koopetycja \\
\hline ryzyko & 0,890 & 3,907 & 1,274 & 1,000 & $0,487^{\star \star \star}$ & $0,437^{\star \star \star}$ & $0,443^{\star \star \star}$ \\
\hline innowacyjność & 0,816 & 4,439 & 1,004 & $0,487^{\star \star \star}$ & 1,000 & $0,624^{\star \star \star}$ & $0,184^{\star \star \star}$ \\
\hline proaktywność & 0,788 & 4,517 & 0,896 & $0,437^{\star \star \star}$ & $0,624^{\star \star \star}$ & 1,000 & $0,128^{\star}$ \\
\hline koopetycja & 0,877 & 3,353 & 1,286 & $0,443^{\star \star \star}$ & $0,184^{\star \star \star}$ & $0,128^{\star}$ & 1,000 \\
\hline wyniki & 0,834 & 3,946 & 0,968 & $0,541^{\star \star \star}$ & $0,454^{\star \star \star}$ & $0,486^{\star \star \star}$ & $0,332^{\star \star \star}$ \\
\hline
\end{tabular}

${ }^{\star} p<0,05 ;{ }^{* \star *} p<0,001$.

Źródto: opracowanie własne.

Wartości współczynników korelacji przedstawione w tabeli 1 wskazują na występowanie w badanej zbiorowości przedsiębiorstw istotnych statystycznie związków pomiędzy koopetycją a gotowością do podejmowania ryzyka i innowacyjnością oraz wynikami osiąganymi przez przedsiębiorstwo, przy czym związek ten określić można jako silny w przypadku gotowości do podejmowania ryzyka. Uzyskane wyniki wskazują zatem na celowość dalszych badań ukierunkowanych na pogłębienie wiedzy o koopetycji i jej związkach z przedsiębiorczością na poziomie organizacji.

\section{Przedsiębiorcze aspekty koopetycji}

W celu szczegółowego określenia znaczenia koopetycji w działaniach przedsiębiorczych wskazane jest odniesienie jej do poszczególnych atrybutów i etapów procesu przedsiębiorczości. Oznacza to odniesienie wcześniej wskazanych aspektów koopetycji do innowacyjności, podejmowania ryzyka i proaktywności. Równocześnie koopetycja może być analizowana w kontekście poszukiwania i identyfikacji sposobności, planowania i mobilizacji zasobów, uruchamiania działalności czy też przedsiębiorczego zarządzania już funkcjonującą organizacją. Bengtsson i Johansson wskazują, że koopetycja może stanowić źródło sposobności dla 
przedsiębiorstw, w szczególności małych i średnich ${ }^{53}$. Przedsiębiorstwa te z powodu specyficznych dla nich ograniczeń mają niewielkie możliwości uczestniczenia w relacjach koopetycyjnych ${ }^{54}$, jednak koopetycja jest wśród nich częstym zjawiskiem, a niekiedy stanowi element ich strategii ${ }^{55}$. Ponadto, jak wskazują Galkina i Lundgren-Henriksson, koopetycja przypomina proces przedsiębiorczy (którego elementami są: działanie w warunkach niepewności, podejmowanie ryzyka, poszukiwanie i wykorzystanie okazji, rozwój innowacji), co dodatkowo uzasadniania analizowanie jej z wykorzystaniem teorii odnoszących się do przedsiębiorczości, a w szczególności procesu przedsiębiorczości ${ }^{56}$. Koopetycja może być rozpatrywana przez pryzmat form i obszarów zastosowania, ale także i korzyści, jakich doświadcza stosujące ją przedsiębiorstwo. W tabeli 2 przedstawiono propozycje stwierdzeń odnoszących się do wskazanych powyżej kontekstów. Odpowiedzi na zaproponowane stwierdzenia mogą być wyrażone w skali Likerta (pięciolub siedmiostopniowej, w zależności m.in. od pozycji i wiedzy osoby dokonującej oceny).

Tabela 2. Propozycje stwierdzeń odnoszących się do wybranych aspektów przedsiębiorczości

\begin{tabular}{|l|l|}
\hline \multicolumn{1}{|c|}{$\begin{array}{c}\text { Aspekt } \\
\text { przedsiębiorczości }\end{array}$} & \multicolumn{1}{|c|}{ Przykładowe stwierdzenia } \\
\hline Innowacyjność & $\begin{array}{l}\text { Wykorzystujemy koopetycję w procesie opracowania innowacji. } \\
\text { Koopetycja umożliwia nam wprowadzanie na rynek innowacji. } \\
\text { Dzięki koopetycji jesteśmy bardziej innowacyjni od innych podmiotów } \\
\text { w naszej branży. }\end{array}$ \\
\hline $\begin{array}{l}\text { Gotowość } \\
\text { do podejmowania } \\
\text { ryzyka }\end{array}$ & $\begin{array}{l}\text { Wykorzystujemy koopetycję w przypadku przedsięwzięć obarczonych } \\
\text { szczególnie dużym ryzykiem. } \\
\text { Koopetycja umożliwia nam ograniczenie ryzyka związanego } \\
\text { z realizowanymi przedsięwzięciami. } \\
\text { Koopetycja umożliwia nam ograniczenie ryzyka związanego } \\
\text { z potencjalnymi wrogimi działaniami konkurentów. }\end{array}$ \\
\hline Wykorzystujemy koopetycję w poszukiwaniu przyszłych trendów. \\
& $\begin{array}{l}\text { Koopetycja umożliwia nam zwiększenie naszych możliwości w zakresie } \\
\text { pozyskiwania informacji/monitorowania otoczenia. } \\
\text { Wykorzystujemy koopetycję w naszych dążeniach do objęcia } \\
\text { przywództwa rynkowego. } \\
\text { Koopetycja umożliwia nam poprawę pozycji rynkowej. }\end{array}$ \\
\hline
\end{tabular}

53 M. Bengtsson, M. Johansson, Managing coopetition to create opportunities for small firms, „International Small Business Journal” 2014, vol. 32, no. 4, s. 401-427.

54 M.H. Morris, A. Koçak, A. Özer, Coopetition as a small business strategy...

55 B. Soppe, C. Lechner, M. Dowling, Vertical coopetition in entrepreneurial firms: theory and practice, „Journal of Small Business and Enterprise Development” 2014, vol. 21 no. 4, s. 548.

56 T. Galkina, E.-L. Lundgren-Henriksson, Coopetition as an entrepreneurial process... 
Tabela 2 (cd.)

\begin{tabular}{|l|l|}
\hline \multicolumn{1}{|c|}{$\begin{array}{c}\text { Aspekt } \\
\text { przedsiębiorczości }\end{array}$} & \multicolumn{1}{c|}{ Przykładowe stwierdzenia } \\
\hline $\begin{array}{l}\text { Poszukiwanie } \\
\text { i identyfikacja } \\
\text { sposobności }\end{array}$ & $\begin{array}{l}\text { Wykorzystujemy koopetycję w poszukiwaniach nowych sposobności } \\
\text { przedsiębiorczych. } \\
\text { Koopetycja umożliwia nam identyfikację nowych sposobności. } \\
\text { Dzięki koopetycji wyszukujemy okazje lepiej od innych podmiotów } \\
\text { w naszej branży. }\end{array}$ \\
\hline $\begin{array}{l}\text { Planowanie } \\
\text { przedsięwzięć }\end{array}$ & $\begin{array}{l}\text { Wykorzystujemy koopetycję, planując nowe przedsiębiorcze działania. } \\
\text { Koopetycja umożliwia nam optymalizację realizowanych procesów. }\end{array}$ \\
\hline $\begin{array}{l}\text { Inicjowanie } \\
\text { działalności }\end{array}$ & $\begin{array}{l}\text { Wykorzystujemy koopetycję na etapie implementacji naszych planów. } \\
\text { Koopetycja umożliwia nam dostęp do zasobów niezbędnych } \\
\text { do uruchomienia działalności. } \\
\text { Koopetycja umożliwia nam skrócenie czasu implementacji naszych } \\
\text { planów. }\end{array}$ \\
\hline $\begin{array}{l}\text { Prowadzenie } \\
\text { działalności }\end{array}$ & $\begin{array}{l}\text { Koopetycja umożliwia nam zwiększenie poziomu przedsiębiorczości } \\
\text { procesu zarządzania. } \\
\text { Koopetycja umożliwia nam zwiększenie efektywności realizowanych } \\
\text { przedsięwzięć. } \\
\text { Koopetycja jest elementem naszej przedsiębiorczej strategii. }\end{array}$ \\
\hline
\end{tabular}

Źródto: opracowanie własne.

Przedstawione w tabeli 2 stwierdzenia nie wyczerpują w pełni problematyki związków pomiędzy koopetycją a przedsiębiorczością na poziomie organizacji. Jednak już to zestawienie wskazuje na wielowymiarowość i złożoność tych powiązań. W konsekwencji pogłębione badania tych powiązań wymagałyby rozbudowanego narzędzia badawczego, a stwierdzenia przedstawione w tabeli 2 stanowiłyby jedynie jego cześć. W przypadku badań odnoszących się do węższego zakresu problemów lub badań, które jedynie częściowo odnoszą się do problematyki koopetycji i przedsiębiorczości, przedstawione w tabeli 2 stwierdzenia mogą być wykorzystywane w zakresie pokrywającym się z celami takich badań.

W pogłębionych analizach dotyczących koopetycji wskazane jest rozróżnienie koopetycji bezpośredniej i pośredniej57, odnoszącej się do działalności podstawowej i uzupełniającej ${ }^{58}$ oraz wskazanie, czy zachodzi ona w diadach, czy w sieciach ${ }^{59}$. Podobnie jak w przypadku badania innych aspektów przedsiębiorczości uwzględnić należy możliwy wpływ charakterystyki przedsiębiorstwa i przedsiębiorcy oraz ekosystemu przedsiębiorczego (w tym warunków prawnych, ekonomicznych, społecznych i kulturowych).

57 Por. S. Kraus i wsp., In search for the ideal coopetition partner...

58 Por. P. Klimas, W. Czakon, Organizational innovativeness...

59 Por. W. Czakon, Network... 
Narzędzie badawcze skonstruowane z wykorzystaniem zaproponowanych powyżej pytań umożliwi określenie roli, jaką odgrywa koopetycja w procesie przedsiębiorczości i na jego poszczególnych etapach, oraz potencjalnych korzyści, jakie oferuje. Ponadto zaproponowane powyżej stwierdzenia mogą być wykorzystane do skonstruowania wskaźników, na podstawie których dokonany zostałby pomiar zależności pomiędzy przedsiębiorczością (i jej wymiarami: innowacyjnością, gotowością do podejmowania ryzyka i proaktywnością) i koopetycją, także w odniesieniu do wyników osiąganych przez przedsiębiorstwa. Wszystkie te elementy mają złożony charakter i określenie ich poziomu wymaga uwzględnienia wielu aspektów, w tym częstotliwości, intensywności, zasięgu i trwałości odpowiadających im zdarzeń.

\section{Podsumowanie}

W poszukiwaniu i wykorzystywaniu okazji przedsiębiorcy mogą zarówno konkurować, jak i współpracować $\mathrm{z}$ innymi podmiotami, w tym także z konkurentami. Umiejętność odpowiedniego kształtowania relacji z innymi podmiotami, w tym ich dopasowanie do wymagań związanych z napotykanymi sposobnościami, staje się ważnym atrybutem przedsiębiorczego działania. Przestawione w opracowaniu rezultaty badań własnych potwierdzają występowanie zależności pomiędzy intensywnością koopetycji a wymiarami orientacji przedsiębiorczej organizacji (gotowością do podejmowania ryzyka i innowacyjnością) oraz wynikami osiąganymi przez przedsiębiorstwo. W świetle powyższego wskazane jest prowadzenie dalszych pogłębionych badań w tym zakresie, a dokonując pomiaru intensywności działań przedsiębiorczych, należy rozważyć uwzględnienie zachowań koopetycyjnych. Dalsze badania dotyczące związków pomiędzy koopetycją a przedsiębiorczością na poziomie organizacji powinny uwzględniać zachowania koopetycyjne w zakresie atrybutów przedsiębiorczości (innowacyjność, proaktywność, gotowość do podejmowania ryzyka) i poszczególnych etapów procesu przedsiębiorczości (poszukiwania sposobności, planowania działań przedsiębiorczych, inicjowania przedsięwzięć czy też zarządzania przedsiębiorczego). Ponadto projektując badania, należy uwzględnić możliwy moderujący wpływ koopetycji na relację pomiędzy wymiarami orientacji przedsiębiorczej a wynikami osiąganymi przez przedsiębiorstwa.

Prowadzenie dalszych badań dotyczących związków pomiędzy koopetycją a przedsiębiorczością wymaga opracowania narzędzi badawczych. W rozdziale zaproponowano zestaw wskaźników odnoszących się do koopetycji w zakresie wybranych atrybutów przedsiębiorczości i etapów procesu przedsiębiorczości. Przedstawione propozycje wymagają jednak dalszej empirycznej weryfikacji. 
Bibliografia

Aluchna M., Kooperencja w grupach kapitałowych, [w:] M. Aluchna, J. Cygler, G. Materna, M.K. Witek-Hajduk, E. Marciszewska, Kooperencja przedsiębiorstw w dobie globalizacji. Wyzwania strategiczne, uwarunkowania prawne, Wolters Kluwer, Warszawa 2013, s. 159-194.

Bengtsson M., Johansson M., Managing coopetition to create opportunities for small firms, „International Small Business Journal" 2014, vol. 32, no. 4, s. 401-427.

Bengtsson M., Kock S., Coopetition in business networks - to cooperate and compete simultaneously, „Industrial Marketing Management” 2000, vol. 29, no. 5, s. 411-426.

Bouncken R., Fredrich V., Ritala P., Kraus S., Coopetition in new product development alliances - advantages and tensions for incremental and radical innovation, „British Journal of Management" 2018, vol. 29, no. 3, s. 391-410.

Boyles T., 21st century knowledge, skills, and abilities and entrepreneurial competences: A model for undergraduate entrepreneurship education, „Journal of Entrepreneurship Education” 2012, no. 15, s. 41-55.

Chin K.S., Chan B.L., Ping-Kit L., Identifying and prioritizing critical success factors for coopetition strategy, „Industrial Management \& Data Systems” 2008, vol. 108, no. 4, s. 437-454.

Crick J.M., Crick D., Developing and validating a multi-dimensional measure of coopetition, „Journal of Business \& Industrial Marketing" 2019, vol. 34, no. 4, s. 665-689.

Cygler J., Kooperencja przedsiębiorstw. Czynniki sektorowe i korporacyjne, Oficyna Wydawnicza SGH - Szkoła Główna Handlowa w Warszawie, Warszawa 2009.

Cygler J., Sroka W., Solesvik M., Dębkowska K., Benefits and Drawbacks of Coopetition: The Roles of Scope and Durability in Coopetitive Relationships, „Sustainability” 2018, vol. 10, no. 2688, s. $1-24$.

Czakon W., Network coopetition, [w:] A.-S. Fernandez, P. Chiambaretto, F. Le Roy, W. Czakon (red.), The Routledge Companion to Coopetition Strategies, Routledge, Abingdon 2018, s. 47-57.

Czakon W., Klimas P., Mariani M., Behavioral antecedents of coopetition: A synthesis and measurement scale, „Long Range Planning” 2020, vol. 53, no. 1, 101875, s. 1-15.

Czernek K., Formy i uwarunkowania koopetycji na obszarach turystycznych, „Przedsiębiorczość i Zarządzanie" 2018, t. XIX, z. 6, cz. II, s. 91-104.

Dyduch W., Pomiar przedsiębiorczości organizacyjnej, Wydawnictwo Uniwersytetu Ekonomicznego w Katowicach, Katowice 2008.

Franco M., Haase H., Firm resources and entrepreneurial orientation as determinants for collaborative entrepreneurship, „Management Decision” 2013, vol. 51, no. 3, s. 680-696.

Galkina T., Lundgren-Henriksson E.-L., Coopetition as an entrepreneurial process: Interplay of causation and effectuation, „Industrial Marketing Management” 2017, no. 67, s. 158-173.

Gartner W.B., „Who Is an Entrepreneur?” Is the Wrong Question, „Entrepreneurship Theory and Practice" 1989, Summer, s. 47-67.

Gnyawali D.R., Park B.J.R., Co-opetition and technological innovation in small and medium-sized enterprises: a multilevel conceptual model, „Journal of Small Business Management” 2009, vol. 47, no. 3, s. 308-330.

Hora W., Gast J., Kailer N., Rey-Marti A., Mas-Tur A., David and Goliath: causes and effects of coopetition between start-ups and corporates, „Review of Managerial Science” 2018, no. 12, s. 411-439.

Hughes M., Morgan R.E., Deconstructing the relationship between entrepreneurial orientation and business performance at the embryonic stage of firm growth, „Industrial Marketing Management" 2007, no. 36, s. 651-661.

Klimas P., Czakon W., Organizational innovativeness and coopetition: a study of video game developers, „Review of Managerial Science” 2018, vol. 12, s. 469-497. 
Kraus S., Meier F., Niemand T., Bouncken R.B., Ritala P., In search for the ideal coopetition partner: an experimental study, „Review of Managerial Studies” 2017, no. 12, s. 1025-1053.

Krupski R., O okazjach raz jeszcze: trochę teorii i raportu z badań, „Przegląd Organizacji” 2012, nr 11, s. 3-5.

Kusa R., Wielowymiarowa analiza przedsiębiorczości organizacyjnej, [w:] A. Zakrzewska-Bielawska (red.), Stan i perspektywy rozwoju nauk o zarządzaniu. Wybrane problemy, Towarzystwo Naukowe Organizacji i Kierownictwa „Dom Organizatora”, Toruń 2016, s. 477-491.

Lumpkin G.T., Dess G.G., The Entrepreneurial Orientation Construct and Linking It to Performance, „Academy of Management Review” 1996, vol. 21, no. 1, s. 135-172.

Mierzejewska W., Czynniki sukcesu koopetycji, „Zarządzanie i Finanse. Journal of Management and Finance" 2018, t. 16, nr 1, s. 123-133.

Miller D., The correlates of entrepreneurship in three types of firms, „Management Science” 1983, vol. 29, no. 7, s. 770-791.

Morris M.H., Kuratko D.F., Corporate Entrepreneurship: Entrepreneurial Development within Organizations, Thomson South-Western, Mason 2002.

Morris M.H., Koçak A., Özer A., Coopetition as a small business strategy: implications for performance, „Journal of Small Business Strategy” 2007, vol. 18, no. 1, s. 35-55.

Nunnally J.C., Bernstein I.H, Psychometric Theory, McGraw-Hill Inc., New York 1967.

Osarenkhoe A., A study of inter-firm dynamics between competition and cooperation - a coopetition strategy, „Journal of Database Marketing \& Customer Strategy Management” 2010, vol. 17, no. 3-4, s. 201-221.

Ribeiro-Soriano D., Urbano D., Overview of collaborative entrepreneurship: An integrated approach between business decisions and negotiations, „Group Decision Negotiation” 2009, no. 18 , s. $419-430$.

Ritala P., Sainio L.-M., Coopetition for radical innovation: technology, market and business-model perspectives, „Technology Analysis \& Strategic Management” 2014, vol. 26, no. 2, s. 155-169.

Rodrigues F., Souza V., Leitão J., Strategic coopetition of global brands: a game theory approach to 'Nike+ iPod Sport Kit' co-branding, „International Journal of Entrepreneurial Venturing” 2011, vol. 3, no. 4, s. 435-455.

Roig-Tierno N., Kraus S., Cruz S., The relation between coopetition and innovation/entrepreneurship, „Review of Managerial Science” 2018, vol. 12, no. 2, s. 379-383.

Rychtowska-Musiał E., Value Creation in a Firm Through Coopetition: Real Options Games Approach, [w:] K. Jajuga, L. Orlowski, K. Staehr (red.), Contemporary Trends and Challenges in Finance. Springer Proceedings in Business and Economics, Springer, Cham 2017, s. 285-295.

Shane S., Venkatraman S., The promise of entrepreneurship as a field of research, „Academy of Management Review" 2000, no. 25, s. 217-226.

Soppe B., Lechner C., Dowling M., Vertical coopetition in entrepreneurial firms: theory and practice, „Journal of Small Business and Enterprise Development” 2014, vol. 21 no. 4, s. 548-564.

Stevenson H.H., Jarillo J.C., A Paradigm of Entrepreneurship: Entrepreneurial Management, „Strategic Management Journal" 1990, vol. 11, no. 4, s. 17-27.

Vanyushyn V., Bengtsson M., Näsholm M.H., Boter H., International coopetition for innovation: are the benefits worth the challenges?, „Review of Managerial Science” 2018, no. 12, s. 535-557.

Walley K., Coopetition: an introduction to the subject and an agenda for research, „International Studies of Management \& Organization" 2007, vol. 37, no. 2, s. 11-31.

Zakrzewska-Bielawska A., Koopetycja a rozwój przedsiębiorstwa w opinii kadry kierowniczej firm high-tech, „Zeszyty Naukowe Politechniki Łódzkiej: Organizacja i Zarządzanie” 2013, nr 52, s. 135-146. 


\section{Streszczenie}

W poszukiwaniu i wykorzystywaniu okazji przedsiębiorcy mogą zarówno konkurować, jak i współpracować $\mathrm{z}$ innymi podmiotami, w tym także konkurentami. Celem rozdziału jest określenie potencjalnych związków pomiędzy przedsiębiorczością organizacyjną a koopetycją. W opracowaniu zaproponowano współczynnik intensywności koopetycji. W wyniku przeprowadzonych badań empirycznych stwierdzono, że jest on istotnie skorelowany zarówno z wymiarami orientacji przedsiębiorczej (gotowością do podejmowania ryzyka i innowacyjnością), jak i wynikami osiąganymi przez przedsiębiorstwa. Zaproponowano pytania, które mogą być wykorzystane do pogłębionej diagnozy zachowań koopetycyjnych, odnoszących się do atrybutów przedsiębiorczości (wymiarów orientacji przedsiębiorczej) i poszczególnych etapów procesu przedsiębiorczości (poszukiwania sposobności, planowania działań przedsiębiorczych, inicjowania przedsięwzięć czy też zarządzania przedsiębiorczego).

Słowa kluczowe: przedsiębiorczość organizacyjna, orientacja przedsiębiorcza, koopetycja, proces przedsiębiorczości, sposobności przedsiębiorcze

\section{Selected aspects of measuring coopetition in the context of entrepreneurial orientation}

\section{Abstract}

In searching and exploring entrepreneurial opportunities, entrepreneurs can both compete and cooperate, also with their competitors. The aim of the paper is to identify possible associations between organisational entrepreneurship and coopetition. In the paper, the coopetition intensity coefficient is proposed. The results of the study show that this coefficient is significantly correlated with dimensions of entrepreneurial orientation (risk-taking and innovativeness) and performance of a firm. Additionally, some research items are proposed, that can be utilized for deeper diagnosis of coopetitive behaviours related to attributes of entrepreneurship (dimensions of entrepreneurial orientation) as well as stages of entrepreneurial process (opportunity identification, entrepreneurial planning, initiating and managing the resulting enterprise).

Keywords: organizational entrepreneurship, entrepreneurial orientation, coopetition, entrepreneurial process, entrepreneurial opportunities 